\title{
TRANSPORT MORSKI KONI W TRAKCIE DZIALAŃ WOJENNYCH BOEMUNDA NA BALKANACH W LATACH 1107-1108
}

Wyprawa wojenna, jaką podjął przeciwko cesarzowi Aleksemu I Komnenowi (1048 - 15 VIII 1118; cesarz od 4 IV 1081) samozwańczy książę Antiochii, Boemund (ok. 1054 - 7 III 1111), w latach 1107-1108 była już przedmiotem wielu badań i analiz ${ }^{1}$. Plany tego zuchwałego Normana, syna Roberta Guiscarda (ok. 1015 - 17 VII 1085), skupiały się na bałkańskich prowincjach Cesarstwa Bizantyńskiego, bowiem ich posiadanie otwierało drogę do stolicy Imperium - Konstantynopola. Boemund zgromadził na południu Italii flotę i wojska lądowe, zapewnił sobie również poparcie papieża Paschalisa (ok. 1055 - 21 I 1118; papież od 13 VIII 1099) i króla Francji Filipa I (23 V 1052 - 29 VII 1108; król od 4 VIII 1060)². Wcześniejsi badacze, zajmujący się ówczesnymi relacjami pomiędzy Normanami z Italii a Bizancjum, skupiali swoją uwagę głównie na działaniach wojennych prowadzonych przez obie strony i na ich związkach dyplomatycznych, pomijając równocześnie wiele innych aspektów, dość istotnych dla ostatecznego rezultatu wojny. Celem niniejszego tekstu jest przedstawienie roli i sposobu transportu morskiego koni normańskich, co miało miejsce podczas zmagań z Bizancjum na Bałkanach w czasie wojny bizantyno-normańskiej z lat 1107-1108.

Pragnąc właściwie zrozumieć istotę poruszanego przez nas problemu należy zastanowić się nad tym, jakie były przyczyny oraz przebieg wyprawy Boemunda na Bizancjum. Konflikt na Bałkanach poprzedziły walki pomiędzy Normanami a Bizancjum na obszarze Cylicji i Syrii, bowiem nowe państwo lewantyńskie Boemunda od czasu powstania kierowało swoją agresję

\footnotetext{
* Dr Marcin Böhm - adiunkt w Katedrze Historii Średniowiecznej w Instytucie Historii na Wydziale Historyczno-Pedagogicznym Uniwersytetu Opolskiego; e-mail: mabohm@wp.pl.

${ }^{1}$ Por. W.B. McQuenn, Relations between the Normans and Byzantium, 1071-1112, „Byzantion” 56 (1986) 427-474; A. Savvides, Byzantino-Normannica. The Norman Capture of Italy and First Two Norman Invasion in Byzantium, Leuven 2007, 71-81; R.B. Yewdale, Bohemond I, Prince of Antioch, Princenton 1924.

${ }^{2}$ Por. Anna Comnena, Alexias XII 1, 1, ed. D.R. Reinsch - A. Kambylis, CFHB 40/1, Berlin 2001, 359; Yewdale, Bohemond I, s. 106-109; E. Albu, Bohemond and the Rooster: Byzantines, Normans and the Artful Ruse, w: Anna Komnene and Her Times, ed. T. Gouma-Peterson, New York - London 2000, 157-158.
} 
przeciwko ziemiom wiernym Cesarstwu. Punktem zwrotnym był moment, w którym Boemund opuścił Antiochię i udał się do Europy Zachodniej prosić o pomoc w konflikcie z Bizancjum 3 . Kością niezgody między Normanem a cesarzem pozostawał status ziem, które wywalczył sobie Boemund na obszarze Syrii kosztem muzułmanów, a które wcześniej wchodziły w skład Bizancjum. Najbardziej drażniąca była sprawa samej Antiochii, jednego z najważniejszych dla chrześcijan miast, które Boemund uczynił swoją stolicą. Samozwańczy książę Antiochii, przywłaszczając sobie tę metropolię, złamał umowę zawarta z Aleksym I w czasie I krucjaty (1096-1099) ${ }^{4}$. Kolejnym czynnikiem prowadzącym do wojny były osobiste animozje władców. Boemund pamiętał doskonale wyprawę, którą prowadził wraz z ojcem przeciwko Cesarstwu na początku lat 80 . XI w., której głównym celem było zbudowanie dla niego na Bałkanach księstwa ${ }^{5}$. Ambitny Norman postanowił, po swoim powrocie do Italii w roku 1105, zniszczyć ostatecznie swego długoletniego rywala i na nowo rozpętać na Półwyspie Bałkańskim działania wojenne, tym razem jednak pod płaszczem walki ideologicznej z odstępcami od ruchu krzyżowego, jakimi w świetle jego propagandy mieli być Bizantyńczycy.

Aleksy I Komnen był świadomy przygotowań Normanów do wojny, dlatego jeden z podległych cesarzowi dowódców, megaduks ${ }^{6}$ Kontostefan (XI/XII w.), przy pomocy powierzonej mu floty miał zatrzymać za wszelką cenę przeprawę Boemunda na Bałkany. Aleksy I przypuszczał, że Normanowie skierują się do Dyrrachium (dzisiejsze Durrës w Albanii), ważnego portu będącego bramą do bałkańskich prowincji Cesarstwa7. Jednak Kontostefan zamiast zachowywać się pasywnie i pilnować powierzonych mu pozycji, przeszedł do działań zaczepnych, uderzając na znajdujące się w rękach Normanów Brindisi, leżące na obszarze Italii ${ }^{8}$. Podczas oblężenia tego miasta przez Bizantyńczyków

${ }^{3}$ Por. Yewdale, Bohemond I, s. 106-109; Albu, Bohemond and the Rooster, s. 157-158.

${ }^{4}$ Por. S. Runciman, Dzieje wypraw krzyżowych, tłum. J. Schwakopf, t. 1, Warszawa 1987, 162; J. Harris, Bizancjum i wyprawy krzyżowe, tłum. J. Gardzińska, Warszawa 2005, 93; R.J. Lilie, Byzantium and The Crusader states, Oxford 1993, 8-12.

${ }^{5}$ Por. Gaufridus Malaterra, De rebus gestis Rogerii Calabriae et Siciliae Comitis et Roberti Guiscardi Ducis fratris eius III 13, ed. E. Pontieri, Rerum Italicarum Scriptores 5/1, Bologna 1928, 64-65; Anna Comnena, Alexias III 9, 1, CFHB 40/1, 109-110; R. Bünemann, Robert Guiskard 10151085, Köln - Weimar - Wien 1997, 113; M. Gallina, Conflitti e coesistenza nel Mediterraneo mediewale: Mondo Bizantino e Occidente Latino, Spoleto 2003, 75; M. Angold, Cesarstwo Bizantyńskie 1025-1204, thum. W. Brodzki, Wrocław - Warszawa - Kraków 1993, 124-125; Savvides, Byzantino-Normannica, s. 39-42.

${ }^{6}$ Stanowisko to możemy porównać z dzisiejszym admirałem floty.

${ }^{7}$ Por. B. Skoulatos, Les personnages byzantins de l'Alexiade: analyse prosopographique et synthèse, Louvain 1980, 130-132; F. Dölger, Regesten der Kaiserkunden des Oströmischen Reiches, t. 2, München 1996, 164, nr 1237 i 166, nr 1241; M. Sesan, La flotte byzantine à l'époque des Comnènes et des Anges (1081-1204), „Byzantinoslavica” 21 (1960) 49; R. Guilland, Le drongaire de la flotte, le grand drongarie de la flotte, le duc de la flotte, le megaduc, ByZ 44 (1951) 212-219.

${ }^{8}$ Por. Anna Comnena, Alexias XII 8, 2-3, CFHB 40/1, 378-379. 
przybyła normańska odsiecz. Ludzie Boemunda pobili i zmusili do ucieczki na okręty bizantyńskiego dowódcę, który pozostawił część swoich wojsk na łasce Normanów9

Boemund wykorzystał nieudolność głównodowodzących bizantyńskich sił morskich. Na czele floty składającej się z dwunastu pirackich okrętów wojennych, jak również z niezidentyfikowanej liczby okrętów transportowych, uderzył jesienią roku 1107 na Bałkany. Wyruszając z Bari, Boemund przyjął oryginalny szyk bojowy. Statki transportowe zamknął w środku swojego ugrupowania bojowego, składającego się ze wspomnianych dwunastu okrętów wojennych. Szyk taki utrudniał z większej odległości dokładne ustalenie liczby, a przede wszystkim rodzaju znajdujących się w nim jednostek. I zapewne taka dezinformacja była celem Boemunda ${ }^{10}$. Norman na cel ataku wybrał port Aulonę (dzisiejsze Vlorë w Albanii), gdzie na kotwicy stała jedna z flotyll bizantyńskich. Cesarski dowódca nie mógł walczyć z przeważającymi siłami wroga, dlatego wycofał się, pozwalając Boemundowi wylądować i zająć miasto. Po zdobyciu portu, Norman wcielił do swoich sił oddział bizantyńskich najemników, pochodzących z Anglii, Hiszpanii i Niemiec, a pełniących rolę załogi Aulony. Rozmieścił ich na wybrzeżu, gdzie znajdowali się pod czujnym okiem jego marynarzy. Następnie idąc szybkim marszem na północ zajmował po kolei wszystkie nadbrzeżne miasta, aż dotarł pod Dyrrachium ${ }^{11}$. Boemund wykorzystał port Aulony, aby wyładować konie swojej jazdy, przewożone przez okręty jego floty.

Możemy spekulować, iż Boemund zakładał, że po zdobyciu Dyrrachium dysponować będzie kolejnym obok Aulony portem, zabezpieczonym od strony lądu potężnymi murami. Norman nie przewidział, że cesarz Aleksy I od czasu przejścia I krucjaty rozbudował umocnienia nowej twierdzy leżącej u ujścia rzeki Elissos. Jej posiadanie przez Bizantyńczyków sprawiało, że Boemund nie był w stanie zamknąć całkowicie pierścienia okrążenia wokół Dyrrachium, gdyż twierdza Elissos pozwalała na ciagłe dostarczanie drogą

${ }^{9} \mathrm{~W}$ tym sporo Turków lub też Turkopoli, którzy służyli w armii bizantyńskiej jako najemnicy. Boemund wykorzystał tych ludzi w swojej antybizantyńskiej kampanii propagandowej. Por. Anna Comnena, Alexias XII 8, 4-5, CFHB 40/1, 379-380; Yewdale, Bohemond I, s. 113; Savvides, Byzantino-Normannica, s. 75-76.

${ }^{10}$ Źródła związane z obozem normańskim podają inne liczby, sugerując równocześnie, że Boemund miał pod swoim dowództwem 230 statków i 34 tys. żołnierzy, co jednak zakwestionujemy później. Por. Anna Comnena, Alexias XII 9, 1, CFHB 40/1, 381; Andreas Dandulus, Chronica pre extensum descripta aa. 46-1280, ed. E. Pastorello, Rerum Italicarum Scriptores 12/1, cz. 1, Bologna - Città di Castello 1938, 226; Yewdale, Bohemond I, s. 115; F. Chalandon, Essai sur le règne d'Alexis I ${ }^{e r}$ Comnène (1081-1118), Paris 1900, 244; J.H. Pryor - E.M. Jeffreys, The Age of Dromon, Leiden 2006, 110; R.J. Lilie, Handel und Politik zwischen dem byzantinishen Reich und den italienischen Kommunen Venedig, Pisa und Genua in der Epoche der Komnenen und der Angeloi (10811204), Amsterdam 1984, 622; Savvides, Byzantino-Normannica, s. 75.

${ }^{11}$ Por. Anna Comnena, Alexias XII 9, 2, CFHB 40/1, 381-382; Savvides, Byzantino-Normannica, s. 76. 
wodną zaopatrzenia do oblężonego miasta ${ }^{12}$. Mając właściwie zabezpieczone Dyrrachium, które mogło długo stawiać opór Normanom, cesarz nie spieszył się z podjęciem działań lądowych przeciwko Boemundowi. Nowemu dowódcy sił morskich skierowanych przeciwko Normanom, wielkiemu drungariosowi floty, Eustacjuszowi Kyminianosowi (XI/XII w.), i pozostałym dowódcom floty, między innymi Kontostefanowi, Aleksy I polecił, by zablokowali wszelką żeglugę pomiędzy Italią a Bizancjum, odcinając tym samym agresora od jego zaplecza ${ }^{13}$.

Dzięki obrońcom Dyrrachium i działaniom swojej floty cesarz zyskał niezbędny czas, który przeznaczył na doszkolenie swoich żołnierzy, szczególnie rekrutów, podczas gdy jego adwersarz dręczony był stale przez nowe trudności różnej natury. Największym problemem było utrzymanie dyscypliny w szeregach Normanów i ich sojuszników. Zdesperowany Boemund spalił na początku wiosny roku 1108 swoje okręty transportowe licząc, że tym gestem zmusi swoich żołnierzy do bardziej zaciętej walki ${ }^{14}$. Do tego czynu Boemunda zmusiło również przybycie floty z Wenecji, która w grudniu roku 1107 połączyła się z Bizantyńczykami, wzmacniając wydatnie siły morskie Aleksego $\mathrm{I}^{15}$. Oblegający Dyrrachium Normanowie wkrótce sami znaleźli się w okrążeniu, gdyż ich oddziałom poszukującym furażu stale przeciwstawiały się jednostki bizantyńskie, które ograniczyły ich pole manewru tylko do najbliższych okolic oblężonego miasta. Z kolei blokada morska uniemożliwiała Normanom ściągnięcie z Italii dodatkowych sił, a przede wszystkim zaopatrzenia. Wśród źle odżywionych Normanów wybuchła wkrótce zaraza, która przerzedziła ich szeregi ${ }^{16}$.

Aleksy I Komnen wspierał działaniami dyplomatycznymi obrońców Dyrrachium, siejąc zamieszanie w obozie normańskim. Cesarz sfingował nawet spisek skierowany przeciwko Boemundowi, a następnie sam też go zdemaskował przy pomocy swojego agenta, znajdującego się w otoczeniu władcy Antiochii ${ }^{17}$. Takie działania cesarza oraz zaciskająca się pętla okrążenia zmusiły Normana do odstąpienia spod Dyrrachium i podjęcia próby przedostania

${ }^{12}$ Por. Anna Comnena, Alexias XII 9, 5-6, CFHB 40/1, 382-383; J. Dudek, ,, Cała ziemia dyrracheńska” pod panowaniem bizantyńskim w latach 1005-1205, Zielona Góra 1999, 68.

${ }^{13}$ Por. Anna Comnena, Alexias XIII 1, 1-4, CFHB 40/1, 384-385; Dölger, Regesten der Kaiserkunden des Oströmischen Reiches, s. 164, nr 1237.

${ }^{14}$ Por. Anna Comnena, Alexias XIII 2, 2, CFHB 40/1, 388.

${ }^{15}$ Por. Annales Venetici breves, ed. H. Simonsfeld, MGH Scriptores 14, Hannoverae 1883, 70, 42-43; Andreas Dandulus, Chronica pre extensum descripta, ed. Pastorello, s. 226; Yewdale, Bohemond I, s. 118.

${ }^{16}$ Por. Anna Comnena, Alexias XIII 2, 4, CFHB 40/1, 389.

${ }_{17}$ Por. tamże XIII 4, 5-9, CFHB 40/1, 395-397; Dölger, Regesten der Kaiserkunden des Oströmischen Reiches, s. 165, nr 1239; Yewdale, Bohemond I, s. 119; Dudek, , Cała ziemia dyrracheńska" pod panowaniem bizantyńskim, s. 71; G.T. Beech, A Norman-Italian Adventurer in the East: Richard of Salerno 1097-1112, „Anglo-Norman Studien” 15 (1993) 37. 
się w głąb półwyspu. Uderzenie Boemunda skierowane zostało na Arbanon, w serce Epiru, gdzie udało mu się rozbić zgrupowanie wojsk bizantyńskich. Jego ludzie podobny sukces odnieśli pod Glabinitzą ${ }^{18}$. Odejście spod murów Dyrrachium i szybki marsz w głąb Bałkanów wskazywać mogą na to, iż Normanowie nie zjedli z braku zaopatrzenia swoich wierzchowców pod tym miastem, gdyż tylko uderzenia ich jazdy mogły przesądzić o obu sukcesach. Nie można również wykluczyć, że część wierzchowców została zdobyta w czasie walk z bizantyńskimi podjazdami w czasie oblężenia Dyrrachium.

Kontruderzenie Bizantyńczyków prowadzone przez Kantakuzena (XI/ XII w.), odniosło znaczący sukces. Było nim zdobycie Mylos, które wcześniej wpadło w ręce Normanów. Gród ten miał wielkie znaczenie strategiczne, ponieważ kontrolował drogę przez rzekę Buse, która była spławna i znajdowały się na niej statki (gr. $\pi \lambda$ ô̂ov), służące do transportu pomiędzy oboma jej brzegami. Normanowie mieli świadomość znaczenia tego punktu i zagrożenia jakie stworzyło zwycięstwo Bizantyńczyków. Kontratak wojsk Boemunda zmusił Bizantyńczyków do opuszczenia Mylos. Wycofujące się oddziały bizantyńskie zdążyły jednak spalić wszystkie statki znajdujące się w tym miejs$\mathrm{cu}$, uniemożliwiając swoim wrogom przeprawę i pościg ${ }^{19}$. Mimo to Normanowie w toku dalszych działań zdołali pokonać kolejne bizantyńskie siły pod dowództwem Michała Kekaumena (XI/XII w.), blokujące drogę w kierunku Jerycha i Kanin ${ }^{20}$. W tym momencie mogło się wydawać, że Boemund odniósł tak mu potrzebne zwycięstwo i Bałkany stały przed nim otworem.

Przesilenie w tej wojnie nastapiło jednak dopiero w kolejnej bitwie pod Mylos. To drugie starcie zakończyło się zwycięstwem strony bizantyńskiej dowodzonej ponownie przez Kantakuzena. Od tej pory fortuna sprzyjała na lądzie Bizantyńczykom. Normanowie byli stopniowo wypierani w kierunku Dyrrachium, tracąc swoje pozycje na obszarze Ilirii i Epiru ${ }^{21}$. Na morzu sytuacja Normanów wyglądała jednak znacznie korzystniej niż parę miesięcy wcześniej. Według relacji Anny Komneny (1 XII 1083 - ok. 1154), Kontostefan dalej źle strzegł przeprawy przez cieśniny, poświęcając zbyt dużo czasu na osobiste rozrywki i schodzenie na ląd, zaniedbując przy tym blokadę, którą zlecił mu prowadzić cesarz. Efektem tej abnegacji było przepuszczenie zbyt wielu okrętów transportowych płynących z Italii, które zdołały dotrzeć do Aulony. Wyładowane tam posiłki i zaopatrzenie zdołały nie niepokojone dotrzeć do Boemunda. To zapewne przybycie tych świeżych sił ułatwiło gwałtowny atak Normanów w głąb Epiru ${ }^{22}$. Możemy być całkiem pewni, iż z Italii

${ }^{18}$ Por. Anna Comnena, Alexias XIII 5, 2-3, CFHB 40/1, 397-398; Dudek, , Cała ziemia dyrracheńska" pod panowaniem bizantyńskim, s. 70.

${ }^{19}$ Por. Anna Comnena, Alexias XIII 5, 5-6, CFHB 40/1, 399.

${ }^{20}$ Por. tamże XIII 5, 7, CFHB 40/1, 399-400.

${ }^{21}$ Por. tamże XIII 6, 2-6, CFHB 40/1, 400-402; Yewdale, Bohemond I, s. 121-122.

22 Por. Anna Comnena, Alexias XIII 7, 2, CFHB 40/1, 403-404; Yewdale, Bohemond I, s. 123; Savvides, Byzantino-Normannica, s. 78 
dowieziono również nowe wierzchowce dla operującej od kilku miesięcy na Bałkanach jazdy normańskiej.

Informacje te wywołały zrozumiały gniew Aleksego I Komnena. Wyznaczony przez niego dowódca bizantyńskiej floty nie potrafił bowiem skutecznie walczyć z jednostkami wroga. Problem polegał na tym, że żeglugę z Italii na Bałkany wspierał wiejący z południa wiatr, który nadawał znacznie większą prędkość statkom normańskim, płynącym pod pełnymi żaglami, i to do tego stopnia że nie musiały one korzystać z napędu wiosłowego. To, co było atutem dla Normanów, dla ich przeciwników było przekleństwem. Płynących pod wiatr Bizantyńczyków, przeciwny ruch powietrza spowalniał i zmuszał wioślarzy ich jednostek do zwiększonego wysiłku ${ }^{23}$. Komnen znalazł jednak potencjalne panaceum na ten problem. Aleksy I narysował mapę brzegów Longobardii i Ilirii wraz z portami, którą wysłał dowódcy floty z listami, w których zalecał mu stawiać na kotwicy okręty w miejscach, w których dogodny wiatr ułatwiał żeglugę po cieśninie, a tym samym walkę z normańską flotą ${ }^{24}$. Groźby i pomoc merytoryczna ze strony cesarza pomogły odzyskać Kontostefanowi sprawność działania. Udało mu się nawet na środku cieśniny lombardzkiej dopaść duży konwój normański, z którego sporo okrętów spalił i posłał na dno ${ }^{25}$. Sukces ten nie ustrzegł go jednak przed utratą stanowiska.

Miejsce niezbyt operatywnego Kontostefana zajął Marian Maurokatakalon (XI/XII w.), który niemal od razu po przejęciu dowództwa nad bizantyńską flotą zdobył cały konwój normańskich statków płynących z pełnym ładunkiem w kierunku bałkańskiego wybrzeża Bizancjum. Wybór Aleksego I okazał się bardzo dobry, gdyż Maurokatakalon wkrótce całkowicie zablokował cieśninę dla statków normańskich ${ }^{26}$. Blokada narzucona przez Maurokatakalona była tak ścisła, że zatrzymywano nawet dwuwiosłowe łodzie (łac. myoparo) płynące z Italii, z żywnością i zaopatrzeniem. Przed zgrupowanymi ponownie pod Dyrrachium Normanami stanęło widmo śmierci głodowej i wybuchła po raz kolejny zaraza. Boemund pod naciskiem swoich ludzi musiał prosić o rozmowy pokojowe ${ }^{27}$. Po długich negocjacjach, we wrześniu 1108 r. Boemund zawarł traktat pokojowy z Aleksym I Komnenem w Diabolis/Dewolu. Znamy jego treść dzięki temu, iż Anna Komnena włączyła jego tekst w swoją relację. W dokumencie tym była między innymi mowa o przekazaniu Aleksemu I Laodycei i innych miast na obszarze Syrii i Cylicji, zdobytych kosztem Bizancjum przez Boemunda i jego ludzi, w szczególności zaś przez jego siostrzeńca Tankreda (ok. 1072-1112). Cesarz zaś ze swojej strony podarował

${ }^{23}$ Por. Anna Comnena, Alexias XIII 7, 3, CFHB 40/1, 404.

${ }^{24}$ Por. tamże XIII 7, 4, CFHB 40/1, 404; Dölger, Regesten der Kaiserkunden des Oströmischen Reiches, s. 166, nr 1241; Yewdale, Bohemond I, s. 124.

${ }^{25}$ Por. Anna Comnena, Alexias XIII 7, 4, CFHB 40/1, 404.

${ }^{26}$ Por. tamże XIII 7, 5, CFHB 40/1, 404-405; Yewdale, Bohemond I, s. 124; P. Sthepenson, Byzantium's Balkanian Frontier, Cambridge 2000, 182.

${ }^{27}$ Por. Anna Comnena, Alexias XIII 8, 5, CFHB 40/1, 406. 
Boemundowi złotą bullę, w której nadał mu dożywotnio ziemie, które Norman odzyskał na Turkach ${ }^{28}$.

Pomiędzy rokiem 1107-1108 flota Boemunda operująca $\mathrm{z}$ baz na obszarze Italii przewoziła wielu żołnierzy, zaopatrzenie oraz wierzchowce. Transport tych ostatnich stanowi główny przedmiot rozważań w niniejszym tekście. Niestety nie mamy zbyt wiele wiarygodnych danych co do sił, jakie Norman zgromadził na wojnę z Bizancjum. Źródła związane z obozem normańskim podają nam różne liczby, którym trudno jednak zaufać. Wedle tych informacji siły morskie Boemunda na początku wojny miały liczyć 230 okrętów, zaś jego wojska od 34 tys. do 72 tys. ludzi, co wydaję się liczbą nieprawdopodobną ${ }^{29}$. Jedynie Anna Komnena podaje chyba faktyczny stan rzeczy, wspominając o 12 pirackich okrętach wojennych, które osłaniały grupę transportowców podczas przeprawy Boemunda do Aulony ${ }^{30}$. Dlaczego te dane są dla nas takie istotne? Otóż dlatego, że znając liczbę okrętów, jesteśmy w stanie określić ilość koni, które można było przetransportować na początku działan, wraz z jeźdźcami i pozostałymi żołnierzami. Przeciętny okręt wojenny używany przez wszystkie strony konfliktu, dromon, był dwurzędową galerą i miał załogę składającą się, w zależności od jego rozmiarów, ze 100 do 200 wioślarzy i marynarzy $^{31}$. Dodatkowo na pokład mógł zabrać do 50 żołnierzy oraz maksymalnie 12 koni $^{32}$. Dysponował również napędem żaglowym (żagiel łaciński), który w połączeniu z napędem wiosłowym był wielkim atutem, zapewniającym niezbędną prędkość szczególnie w czasie walki. Gdybyśmy zatem przyjęli liczbę okrętów podawaną przez źródła łacińskie za prawdziwą i uznali dodatkowo, że większość z nich stanowiły okręty wojenne, otrzymamy liczbę ok. 30 tys. żeglarzy i żołnierzy, którzy musieliby obsłużyć taką flotę Boemunda. Idąc tym tokiem myślenia dojść można do wniosku, że Normanowie mieliby w jednym rzucie do 3 tys. koni, które mogłyby zostać zaokrętowane, co jest przecież niezwykle dużą liczbą. Dla porównania całe siły morskie Bizancjum w X w. mogły wystawić ok. 34 tys. marynarzy (wraz z żołnierzami piechoty morskiej) ${ }^{33}$.

${ }^{28}$ Por. tamże XIII 12, 1-28, CFHB 40/1, 413-423; Dölger, Regesten der Kaiserkunden des Oströmischen Reiches, s. 166-167, nr 1243; Я.Н. Любарский - М.М. Фрейденберг, Девольский договор 1108 г. Между Алексеем Комнином и Боэмундом, „Византийский Временник” 21 (1962) 260-274; Yewdale, Bohemond I, s. 127-130; Dudek, ,CCała ziemia dyrracheńska” pod

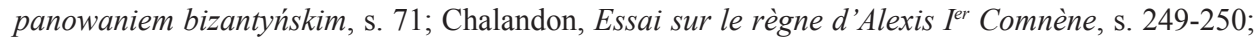
McQuenn, Relations between the Normans and Byzantium, s. 466; Beech, A Norman-Italian Adventurer in the East, s. 37-38; Sthepenson, Byzantium's Balkanian Frontier, s. 182-183.

${ }^{29}$ Szerzej na temat analizy pronormańskich źródeł łacińskich zob. Yewdale, Bohemond I, s. 115.

${ }^{30}$ Por. Anna Comnena, Alexias XII 9, 1, CFHB 40/1, 381.

${ }^{31}$ Por. M. Bonino, Archeologia navale, w: Storia di Ravenna, vol. 2/1, Ravenna 1991, 40-41; V. Christides, Two Naval Guides of the Tenth Century:Qudamas Document and Leo VI's Naumachica: A study on Byzantine and Moslem Preparedness, „Graeco-Arabica” 1 (1982) 61-62; R. Dolley, The Warships of the Later Roman Empire, JRS 38 (1948) 47-53.

${ }^{32}$ Por. Pryor - Jeffreys, The Age of Dromon, s. 323.

${ }^{33}$ Por. tamże, s. 548-570, Aneks nr 4: Fleets, armaments, and equipment for dromons, pamfyloi 
Ilość okrętów (230) podawana w źródłach łacińskich jest wielka i możemy ją jedynie porównać z potencjałem potęg morskich Arabów i Bizantyńczyków we wcześniejszych wiekach, czy z imperiami morskimi Wenecji i Genui w czasach późniejszych. Utrzymanie takiej floty sprawiałoby również szereg problemów logistycznych i byłoby niewyobrażalnym obciążeniem dla skarbca Boemunda, tym bardziej że jego włości w południowej Italii zostały wcześniej bardzo okrojone na korzyść jego przyrodniego brata Rogera (ok. 1060 - 22 II 1111), nie bez kozery przezwanego Sakwą (Borsa) ${ }^{34}$.

Jeśli jednak przyjmiemy, iż źródła łacińskie nie podają błędnych informacji i że Boemund faktycznie zgromadził takie siły morskie, to wówczas rodzi się pytanie, skąd te okręty mogłyby pochodzić? Wiemy, że Boemund w czasie walk z Bizantyńczykami w Syrii korzystał z wsparcia floty miasta Pizy $^{35}$. W czasie przygotowań do wojny z Aleksym I, Norman zapewnił sobie pomoc króla Francji i papieża, którą zdobył dzięki umiejętnym rozgrywkom politycznym. Jego siostrzeniec Tankred, pełniąc funkcję regenta Antiochii, sprzymierzył się przeciwko Bizancjum z Genueńczykami i korzystał z pomocy ich floty pod Laodyceą ${ }^{36}$. Zarówno Piza, jak i Genua były wrogo nastawione do Bizancjum, którego flota ścierała się intensywnie z siłami morskimi tych komun miejskich w okresie kilku lat po zakończeniu I krucjaty ${ }^{37}$. Jedynie Wenecja pozostawała w sojuszu z Bizancjum, czynnie walcząc ze swoją konkurencją po stronie Aleksego I Komnena ${ }^{38}$. Jednakże zarówno Piza, jak i Genua w momencie rozpoczęcia działań wojennych zajęte były umacnianiem swoich pozycji w państwach krzyżowców i to pochłaniało większość ich potencjału morskiego ${ }^{39}$. Boemund nie mógł zatem liczyć na zbyt dużą pomoc $\mathrm{z}$ ich strony. Normanowi pozostało jedynie wsparcie rodziny (z którą nie był w zbyt dobrych stosunkach). Zdobywca Antiochii wykorzystał także swoje skromne italskie włości oraz (zapewne) licznych najemników, którzy ciągnęli pod jego sztandary.

and ousiaka chelendia according to the inventories from the expeditiones to Crete of 911 and 949 in the De Ceremoniis Aulae Byzantinae attributed to Constantine VII Porphyrogennetos.

${ }^{34}$ Por. E. Cuozzo, Roger Borsa, w: Lexikon des Mittelalters, vol. 7, München 1999, 938-939.

${ }^{35}$ Por. Anna Comnena, Alexias XI 10, 6, CFHB 40/1, 352; Pryor - Jeffreys, The Age of Dromon, s. 110; Lilie, Handel und Politik, s. 617.

${ }^{36}$ Por. Anna Comnena, Alexias XI 7, 7, CFHB 40/1, 345; Runciman, Dzieje wypraw krzyżowych, t. 2, s. 41-42; J. Holiefield, Tancred and Bohemond: brothers-in-arms or arch rivals, Leeds 2007, 31; Lilie, Handel und Politik, s. 346.

${ }^{37}$ Por. Anna Comnena, Alexias XI 10, 4, CFHB 40/1, 351; Caffarus Genuensis, Annales Genuenses, a cura di L.T. Belgrano: Annali Genovesi di Caffaro e de' suoi continuatori dal MXCIX al MCCXCIII, vol. 1, Fonti per Storia d'Italia 11, Genova - Roma 1890, 121; Lilie, Handel und Politik, s. 621; Skoulatos, Les personnages byzantins de l'Alexiade, s. 77; Pryor - Jeffreys, The Age of Dromon, s. 110.

${ }^{38}$ Por. Andreas Dandulus, Chronica pre extensum descripta, ed. Pastorello, s. 221; Lilie, Handel und Politik, s. 617.

${ }^{39}$ Por. Pryor - Jeffreys, The Age of Dromon, s. 107. 
Wróćmy jednak do kluczowej w tej kwestii relacji Anny Komneny. Dwanaście okrętów wojennych oraz pewna grupa okrętów transportowych (być może 30 do 50 jednostek) wymagało o wiele mniejszych nakładów i środków finansowych. Czy takie siły morskie były zdolne zagrozić bizantyńskiej flocie pilnującej Cieśniny Longobardzkiej lub też w spokoju wyładować swoich pasażerów wraz z ich wierzchowcami na Bałkanach? Dla porównania możliwości obronnych Bizancjum musimy się odwołać do wcześniejszego okresu. Wiemy, że wzorcowe pod względem składu eskadry bojowe bizantyńskiej floty wojennej, pochodzące $\mathrm{z}$ temu morskiego Kibyrraioton, liczyły w wiekach wcześniejszych 24 okręty typu dromon/chelandia ${ }^{40}$. Niestety nie mamy tak dokładnych danych co do wielkości bizantyńskich eskadr dla początków XII stulecia, gdyż wtedy flota Kibyrraioton już nie istniała, zaś cesarz Aleksy I wprowadził szereg zmian w sposobie funkcjonowania sił morskich i wystawiania okrętów przez poddanych Cesarstwa. Basileus zmagać się musiał ciągle z brakiem wystarczającej liczby okrętów dla zapewnienia całkowitego bezpieczeństwa wszystkich granic morskich Cesarstwa. Początkowo w działaniach na morzu korzystał z pomocy jednostek Wenecji, później zaś starał się własnymi siłami morskimi powstrzymywać wrogów zewnętrznych ${ }^{41}$. Bizancjum pod jego władzą było zdolne do zgromadzenia sił morskich liczących nawet do 60 okrętów wojennych, co poświadcza nam źródło genueńskie ${ }^{42}$.

Należy w tym miejscu również przypomnieć, iż na początku wojny z Boemundem to Bizantyńczycy jako pierwsi uderzyli na normańskie Brindisi, pod którym ponieśli klęskę. Porażka musiała być okupioną utratą nie tylko załóg, ale zapewne również okrętów, które stacjonowały wcześniej w iliryjskich portach Bizancjum. Tych okrętów musiało zabraknąć w czasie lądowania

${ }^{40}$ Była to flota służąca do szybkiego reagowania na zagrożenia dla bezpieczeństwa granic morskich Bizancjum, głównie ze strony Arabów. Por. Ioannes Scylitzes, Synopsis Historiarum, ed.

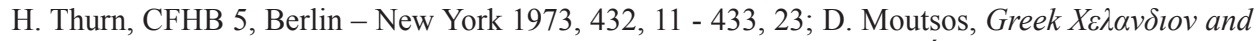
latin Celundria, „Byzantion” 62 (1992) 412-413; H. Antoniadis-Bibicou, Études d'histoire maritime de Byzance. A propos du Thème des Caravisiens, Paris 1966, 63-68; A. Savvides, The Secular Prosopography of the Byzantine Maritime Theme of the Carabisians/Cibyrraeots, „Byzantinoslavica” 59 (1998) 24-45.

${ }^{41}$ Za co Wenecja otrzymała przywileje handlowe na obszarze Cesarstwa. Por. Anna Comnena, Alexias VI 5, 10, CFHB 40/1, 178-179; Andreas Dandulus, Chronica pre extensum descripta, ed. Pastorello, s. 217; Dölger, Regesten der Kaiserkunden des Oströmischen Reiches, s. 93-94, nr 1081; D. Jacoby, The Chrysobull of Alexius I Comnenus to the Venetians: the date and the debate, „Journal of Medieval History” 28 (2002) 199-204; E. Frances, Alexis Comnene et les privileges octroyes a Venise, „Byzantinoslavica” 29 (1968) 17-23; G. Tuma, The Dating of Alexius Chrysobull to the Venatians: 1082, 1084, or 1092?, „Byzantinoslavica” 42 (1981) 171-185; M.E. Martin, The Chrysobull of Alexius I Comnenus to the Venetians and Early Vetian Quarter in Constantinopole, „Byzantinoslavica" 39 (1978) 19-23; J.E. Dotson, Foundations of Venetian Naval Strategy from Pietro II Orseolo to the Battle of Zonchio, „Viator” 32 (2001) 114; K.N. Ciggaar, Western Travellers to Constantinopol, Leiden - New York - Köln 1996, 267.

${ }^{42}$ Por. Caffarus Genuensis, Annales Genuenses, a cura di Belgrano, s. 117-118. 
Normanów, a straty takie trudno było szybko uzupełnić. Wiemy jednak, że Komnenowi udało się odtworzyć na czas zdolność bojową floty na tym odcinku, ale zawiódł głównodowodzący nią Kontostefan. To w dużej mierze z powodu błędów tego człowieka, ale również dzięki sprytowi Boemunda, udało się lądowanie i zajęcie portu w Aulonie. Boemund doskonale wiedział, że - aby bezpiecznie wylądować - będzie musiał jakoś zneutralizować siły Bizancjum na morzu. Dlatego uciekł się do podstępu w celu stworzenia wrażenia posiadania większej ilości jednostek bojowych, niż miał ich w rzeczywistości. Jak już wspomniano, wszystkie transportowce umieścił wewnątrz swojego szyku bojowego, zaś okręty wojenne ,opasywały je” być może na zasadzie okręgu. Transportowce wiozły cenny ładunek, wierzchowce i jeźdźców oraz piechotę i dlatego Boemund musiał je chronić za wszelką cenę. Pojedyncze jednostki patrolowe Bizantyńczyków, które w momencie przeprawy Normana znajdowały się na morzu, nie były w stanie nawiązać walki z okrętami Boemunda, a wycofując się do portów wzbudzały zapewne panikę, czego przykładem może być sytuacja spod Aulony. Okręty Kontostefana umieszczone w szeregu portów, takich jak wspomniana Aulona i Dyrrachium, i tworzące zapewne eskadry liczące maksymalnie kilkanaście sztuk, nie były w stanie samodzielnie podjąć równorzędnej walki z liczącą kilkadziesiąt jednostek flotą Boemunda, tym bardziej że nie znały jej faktycznej liczebności, gdyż zawiódł wówczas całkowicie wywiad bizantyński.

Okręty wojenne używane przez Normanów, najczęściej tego samego typu co dromon/chelandia, nie były zbyt dobrze przystosowane do transportu koni, który wymagał dodatkowych zmian w konstrukcji statków i okrętów, jak również znacznie obniżał ich prędkość. Znajdująca się w pracy Davida Nicolle i Angusa McBride’a ilustracja pokazuje przykładowe rekonstrukcje jednostek używanych przez Normanów na Morzu Północnym i Śródziemnym. Dla nas najbardziej istotne są dwa przykłady (nr 1 i 3$)^{43}$. Pierwszy przykład przedstawia typowy okręt transportowy, używany przez państwa basenu Morza Śródziemnego (w tym Bizancjum i Normanów) w interesującym nas okresie. Przykład drugi pokazuje zaś z profilu dwurzędowy dromon, będący typową jednostką wojenną. Transportowiec miał znacznie wyższe burty i specjalnie przystosowane do transportu koni ładownie, których brakowało dromonowi. Mógł również zabrać na swój pokład znacznie więcej ludzi, niż jednostki bojowe. Okręty wojenne o smukłej budowie bywały jednak dość często wykorzystywane do transportu koni, choć ich możliwości załadunkowe nie mogły się równać z tymi, którymi dysponowały transportowce. Dzięki badaniom Johna Pryora wiemy, że 12 koni okrętowano w specjalnie przystosowanych miejscach wzdłuż kilu pod pokładem dromonu, pomiędzy dwoma rzędami wioślarzy. Konie nie stały bezpośrednio na poszyciu okrętu, lecz na specjalnie

${ }^{43}$ Por. D. Nicolle - A. McBridea, Normans, London 1995, plansza L: Okręty średniowiecznych Normanów. 
przygotowanych deskach, które musiały wytrzymać wagę ponad 6 ton (gdyż tyle ważyło 12 wierzchowców). Wierzchowce pętano tak, aby cały czas stały, co przy dłuższych podróżach wpływało negatywnie na ich kondycję. Na potrzeby koni przeznaczano dziennie 430 litrów wody. Ograniczona ilość wody w wypadku dłuższej podróży była sporym problemem. Dodając do tego paszę i ekwipunek jeździecki otrzymamy dodatkowe kilka ton. Dlatego zdaniem tego badacza do transportu koni najczęściej na Morzu Śródziemnym w tym okresie wybierano okręty żaglowe, gdyż można było na nie załadować znacznie więcej wierzchowców (od 20 do 30 sztuk). Kolejnym atutem żaglowców w stosunku do galer wojennych były mniejsze załogi (na żaglowcach nie występował problem z wioślarzami, którzy wraz z zapasami wody i żywności byli dodatkowym obciążeniem jednostki $)^{44}$.

Jak słusznie zauważa jednak J. Pryor, trudno takim okrętem żaglowym wypełnionym końmi wylądować bezpiecznie na plaży, bez ryzyka zniszczenia jednostki. Żaglowce potrzebowały portu, aby wyładować zaokrętowane na nie konie przy pomocy specjalnych ramp/pomostów. Inaczej ma się sprawa z dromonami/chelandiami, z których wierzchowce wraz z jeźdźcami można było wysadzać z ramp w płytkiej wodzie w pobliżu plaż ${ }^{45}$. Normanowie z południowej Italii dysponowali sporym doświadczeniem $\mathrm{w}$ operacjach wymagających transportu morskiego koni. Po raz pierwszy z takimi działaniami spotykamy się w lutym roku 1061, gdy Roger (ok. 1030 - 22 VI 1101), wuj Boemunda, wraz z grupą 60 rycerzy dokonał rekonesansu lądując w pobliżu Messyny ${ }^{46}$. W marcu tego samego roku Roger wysłał na Sycylię grupę 150 rycerzy, która została przewieziona przez Cieśninę Messyńską i wysadzona na plaży w pobliżu Rometty ${ }^{47}$. Obydwie te wyprawy miały za zadanie dokonać walką rozpoznania możliwości obronnych sycylijskich muzułmanów, jak również przygotować Normanów do dalszych działań desantowych. Normanowie lądowali na plażach i stamtąd na swoich wierzchowcach wyruszali na grabieżcze rajdy. W maju 1061 r., Roger rozpoczynając podbój Sycylii przekroczył nocą cieśninę wraz z 300 rycerzami, którzy również byli desantowani na plażach ${ }^{48}$. To tylko wybrane przypadki, bowiem normański podbój Sycylii pełen jest tego typu operacji. By jednak poszukać nieco bliższych czasowo przykładów, warto przypomnieć, że w roku 1081 ojciec Boemunda, Robert Guiscard, również zgromadził liczną flotę, na czele której udał się na Bałkany ${ }^{49}$. Atak poprzedziło lądowanie oddziału jazdy pod dowództwem Boemunda, którego zadaniem była osłona desantu sił głównych. Norman rozpoczął swoją akcję na przełomie marca i kwietnia 1081 r. Boemund po wylądowaniu na wybrzeżu albańskim

\footnotetext{
${ }^{44}$ Por. Pryor - Jeffreys, The Age of Dromon, s. 325-329.

${ }^{45}$ Tamże, s. 307.

${ }^{46}$ Por. Gaufridus Malaterra, De rebus gestis Rogerii II 1, 3, ed. Pontieri, s. 29-30.

${ }^{47}$ Por. tamże II 5-6, ed. Pontieri, s. 31; G.A. Loud, The Age of Robert Guiscard, Harlow 2000, 149.

${ }^{48}$ Por. Gaufridus Malaterra, De rebus gestis Rogerii II 12, ed. Pontieri, s. 33.

${ }^{49}$ Por. Anna Comnena, Alexias, III 9, 1, CFHB 40/1, 110.
} 
zajął właśnie Aulonę i Jerycho, po czym ruszył w kierunku północnym na Butrinto, gdzie jego siły miały połączyć się z siłami Roberta ${ }^{50}$.

Jak zatem widać Boemund był doświadczonym wodzem, który potrafił skutecznie wykorzystać siły morskie, aby zaskoczyć przeciwnika, a następnie przy pomocy jazdy zniszczyć jego wojsko. Istotne jest także i to, że znał on dobrze teatr zmagań, bowiem przebywał na nim dwukrotnie: raz w czasie wojny bizantyno-normańskiej z lat 1081-1085, a drugi podczas I krucjaty ${ }^{51}$. Małe siły morskie, którymi dysponował Boemund, wymuszały na nim przyjęcie podobnej taktyki lądowania jak ta $\mathrm{z}$ roku 1081. Te kilkadziesiąt okrętów floty Boemunda miało za zadanie wyładować awangardę sił normańskich i zdobyć przyczółek na Bałkanach. Zakładając, zgodnie z ustaleniami J. Pryora, że na 12 okrętach wojennych (dromonach) Boemunda znajdować się mogły 144 wierzchowce wraz z jeźdźcami, plus ok. 600 żołnierzy piechoty, możemy powiedzieć, że taki oddział miał wystarczającą siłę bojową do przeprowadzenia powierzonego mu zadania. Dodając do tego jeźdźców znajdujących się na transportowcach (przy założeniu, że jednostek tych było ok. 30, a na każdej z nich znajdowało się ok. 30 koni), otrzymamy prawie tysiąc jeźdźców i ok. 3 tys. piechoty. Taka armią jak na warunki średniowiecza była już znaczną siłą. Tylu ludzi wraz z zaopatrzeniem mogło swobodnie rozpocząć działania wojenne, zająć i utrzymać Aulonę, jak również miejscowości znajdujące się przy drodze z tego miasta do Dyrrachium.

Boemund zapewne celowo wybrał Aulonę jako miejsce swojego pierwszego lądowania ${ }^{52}$. Mając w swoich rękach normalny port, nie musiał desantować wszystkich swoich jeźdźców bezpośrednio na plażach. Konie wysadzane w takich warunkach były bowiem bardziej narażone na kontuzje, niż w czasie normalnego wyładunku. Pamiętać należy również o ryzyku utonięcia desantowanych rycerzy, które mogło nastapić, gdyby któryś z dowodzących okrętem źle obliczył głębokość wody w pobliżu brzegu. W tym miejscu musimy się znów odwołać do kolejnej współczesnej rekonstrukcji. Praca wykonana wspólnie przez wybitnego badacza stosunków bizantyno-italskich w średniowieczu D. Nicolle i rysownika A. McBride'a ukazuje przebieg lądowania wojsk normańskich w pobliżu brzegów ${ }^{53}$. Jak wynika $\mathrm{z}$ tej rekonstrukcji, ko-

${ }^{50}$ Por. Andreas Dandulus, Chronica pre extensum descripta, ed. Pastorello, s. 216; Dudek, „Cała ziemia dyrracheńska” pod panowaniem bizantyńskim, s. 51; Bünemann, Robert Guiskard 1015-1085, s. 114; Yewdale, Bohemond I, s. 13.

${ }^{51}$ Por. Anna Comnena, Alexias X 8, 1, CFHB 40/1, 303-304; J.H. Pryor, Introduction: modelling Bohemond's march to Thessalonike, w: Logistics of Warfare in the Age of the Crusaders, ed. J.H. Pryor, Cambridge 2007, 1; J. Shepard, When Greek meets Greek: Alexius Comnenus and Bohemond in 1097-1098, „Byzantine and Modern Greek Studies” 12 (1988) 186-211.

${ }_{52}$ Por. A.P. Kazhdan, Avlon, w: The Oxford Dictionary of Byzantium, ed. Kazhdan et al., vol. 1, Oxford - New York 1991, 238.

${ }^{53}$ Por. Nicolle - McBride, Normans, plansza G: Desant normańskiej jazdy i piechoty w pobliżu brzegów w XII stuleciu w poludniowej Italii. 
nie wysadzano po rampie znajdującej się od strony rufy statku, w tym wypadku okrętu wojennego o napędzie wiosłowo-żaglowym. Taki sposób podejścia okrętów do brzegu zapewniał dromonom/chelandiom możliwość szybkiego opuszczenia wrogich wód po zakończeniu wyładunku. Do tego typu działań wykorzystywano napęd wiosłowy. Tą metodą stosunkowo szybko można było także wyładować zaopatrzenie, szczególnie zapasy paszy dla koni, niezbędne aby wierzchowce mogły funkcjonować w warunkach bojowych. Nie możemy wykluczyć możliwości, że właśnie w ten sposób pod Auloną 12 okrętów Boemunda wyładowało znajdujących się na ich pokładach rycerzy i piechotę, którzy następnie opanowali instalacje portowe tego miasta. Boemund zajmując port zdolny pomieścić większość jego floty, a takim była w tamtym czasie Aulona, mógł w niemal komfortowych warunkach wysadzić całość znajdujących się na jego transportowcach sił, a nie tylko te, które załadowane były na dromony/chelandie. Aulona jako port leży $130 \mathrm{~km}$ (70 mil morskich) od Bari, co w wypadku wyprawy takiej jak ta podjęta przez Boemunda w latach 1107-1108 ma strategiczne znaczenie. Transport morski w jedną stronę na tak krótkim odcinku, przy przeciętnej prędkości dromonu/żaglowca wynoszącej ok. 4 węzłów, trwał jeden dzień ${ }^{54}$. Anna Komnena wspomina, że okręty Normanów, wypływające z portów południowej Italii, dzięki porywom południowego wiatru poruszały się znacznie szybciej niż jednostki bizantyńskie. Taki wiatr mógł mieć sporą siłę nośną i zwiększać prędkość płynących pod żaglami oraz wiosłami statków nawet do 7 węzłów. Płynące pod taki wiatr jednostki Bizantyńczyków miały marne szanse, aby doścignąć okręty i statki normańskie. Duża prędkość okrętów floty Boemunda miała wielkie znaczenie dla kondycji koni, gdyż zwierzęta krócej były narażone na stres i różne niebezpieczeństwa związane z podróżą morską. Do przerzucenia nawet sporych sił na tak krótkim odcinku, nie potrzeba było zatem zbyt wielkiej floty transportowej, bowiem przy sprzyjających warunkach pogodowych w ciagu tygodnia mała flota Boemunda mogła przewieźć całość jego armii na Bałkany. Aulona do końca wojny była portem, do którego kierowały się transporty z wojskiem i zaopatrzeniem po przedarciu się przez bizantyńską blokadę. Możemy zatem uznać, że miasto to odgrywało kluczową rolę w wyładunku następnych dostaw wierzchowców dla wojsk Normanów.

Dalszy przebieg działań wojennych wskazuje jednoznacznie, że Boemund od samego początku wyprawy nie dysponował zbyt duża ilością okrętów, zarówno wojennych jak i transportowych, co zdaje się potwierdzać nasze wcześniejsze wnioski. Norman nie był w stanie utrzymać przez dłuższy czas połączenia morskiego na linii Bari-Aulona. Połączone floty Wenecji i Bizancjum operujące na Adriatyku zdołały całkowicie uniemożliwić mu kontakt z zapleczem w Italii. Wiemy, że Boemund pod Dyrrachium miał ze sobą pewną część

${ }^{54}$ Por. Pryor - Jeffreys, The Age of Dromon, s. 340-341; S. Ducin, Sztuka nawigacji w starożytnej Grecji i Rzymie, Lublin 1997, 73-76. 
swojej floty. Możliwe zatem, że ta służyła mu jedynie za łącznik z bazą zaopatrzeniową w Aulonie. To Aulona musiała dostarczać żywność i paszę walczącym pod Dyrrachium Normanom. Rosnąca supremacja Bizantyńczyków na morzu zablokowała jednak i te dostawy, więc pragmatyczny Boemund rozkazał spalić swoje jednostki znajdujące się w pobliżu jego obozu ${ }^{55}$. Do Aulony zaś dalej docierały transporty z zaopatrzeniem dla Normanów płynące z Italii, które wykorzystywały zarówno nieuwagę Bizantyńczyków, jak i sprzyjający wiatr. Nie wiemy niestety, ile koni były w stanie dostarczyć Normanom te jednostki i czy dostawy wierzchowców trwały do końca działań wojennych. $\mathrm{Z}$ drugiej strony Normanowie stracili zapewne, walcząc w trudnym górzystym terenie Epiru, wielką liczbę swoich wierzchowców. Takie starty wynikały w dużej mierze z tego, że bizantyńscy łucznicy wiedzieli doskonale, że największym atutem najeźdźców jest ich jazda. Nie mogąc zatem specjalnie zaszkodzić ubranym w kolczugi jeźdźcom, strzelali do nieopancerzonych koni ${ }^{56}$. W podobny sposób musieli rozumować marynarze Aleksego I Komnena, którzy polowali szczególnie zawzięcie na okręty transportowe. Wiele tego typu jednostek wpadło w ich ręce lub zostało przez nich zatopionych. Nie wiadomo ile wierzchowców przewożonych przez te transportowce dostało się $\mathrm{w}$ ręce Bizantyńczyków. Możemy jedynie spekulować, że była to liczba znaczna.

Konie bojowe normańskiej jazdy stanowiły podstawę sukcesów militarnych Boemunda, bowiem skuteczne ich wykorzystanie zmieniało przebieg bitew na korzyść Normanów, nawet przy znacznej przewadze nieprzyjaciela. Wierzchowce normańskiego rycerstwa odegrały w czasie wojny bizantyno-normańskiej z lat 1107-1108 istotną rolę. To one zapewniały Normanom mobilność i dużą siłę uderzeniowa, oraz przyczyniły się do kilku zwycięstw Boemunda na Bałkanach. By jednak utrzymać tę szczęśliwą dla siebie passę, Normanowie musieli zapewnić sobie stałe dostawy wierzchowców oraz paszy dla nich. Ojczyzną większości ich koni była południowa Italia, skąd dostarczano je dla nich drogą morską. Jednakże wobec przewagi na morzu sił Aleksego I, stale rosnące straty nie były uzupełniane i pod koniec wojny jazda Boemunda nie była w stanie skutecznie walczyć z Bizantyńczykami. Pozbawiony swojej najgroźniejszej broni ambitny Norman musiał się poddać na warunkach narzuconych mu przez cesarza. Umiejętne zablokowanie transportu koni i żywności miało kluczowe znaczenie dla losów konfliktu Bizancjum z Normanami.

${ }^{55}$ Możliwe, że chodziło o 12 okrętów wojennych, z którymi wyruszył kilka miesięcy temu na podbój Bałkanów.

${ }^{56}$ Większość łuczników była wtedy pochodzenia tureckiego. Najczęściej byli to Pieczyngowie, Uzowie lub Kumani wciagnięci na służbę u cesarza Aleksego I Komnena. Źródła związane z obozem krzyżowców przyjęły od Bizantyńczyków ich nazwę - Turkopolów. Por. Runciman, Dzieje wypraw krzyżowych, t. 2, s. 266; Y. Harare, The Military Role of the Frankish Turcopoles: A Reassement, „Mediterranean Historical Reviev” 12 (1997) 75-116. 


\section{THE TRANSPORT OF NORMAN HORSES DURING THE WAR OF BOEMUND WITH BYZANTIUM IN 1107-1108}

(Summary)

The Bohemond of Tarentum Expedition of 1107-1108, directed against the Byzantine Empire, was one of the key steps in Normans relations with the Byzantine Empire in the twelfth century. Preceded by a great propaganda campaign, had to bring the emperor Alexius I Komnenos to his knees. After initial successes, the Normans succumbed to Byzantium. The Byzantines focused their attention on the elimination of the Normans cavalry. This formation could not function without adequate mounts and supplies for them. By blocking the supplies coming from Italy, while in the same time eliminating the horses which were in the hands of the invaders, the Byzantines prejudged the outcome of the conflict.

Key words: Byzantium, Navy, Alexios I, Boemund I, Balkans.

Słowa kluczowe: Bizancjum, Flota, Aleksy I, Boemund I, Bałkany. 